\title{
Coffee biotechnology
}

\author{
César De Los Santos-Briones and S. M. Teresa Hernández-Sotomayor*
}

Unidad de Bioquímica y Biología Molecular de Plantas, Centro de Investigación Científica de Yucatán A.C., Calle 43 No. 130, Chuburna de Hidalgo, C.P.97200, Mérida, Yucatán, México.*Corresponding author: ths@cicy.mx

In the last three decades, interest has turned to in vitro cell culture in different areas of coffee research. In vitro techniques have been applied not only for coffee improvement through genetic transformation but also to study various aspects in coffee cells such as chemical (caffeine synthesis and the production of coffee aroma), physiological and more recently, biochemical aspects. The most important advances obtained to date on in vitro coffee techniques in fields like biochemistry, physiology, regeneration systems and genetic engineering, are presented and discussed.

Keywords: Coffea, coffee, genetic transformation, in vitro tissue culture, regeneration, somatic embryogenesis.

Biotecnologia do café: Nas últimas três décadas tem sido dada atenção para a cultura de células in vitro em diferentes áreas da pesquisa com café. Técnicas in vitro têm sido aplicadas não somente para o melhoramento do café, através da transformação genética, mas também para o estudo de vários aspectos, tais como químicos (síntese de cafeína e a produção de aroma), fisiológicos e, mais recentemente, bioquímicos. Os avanços mais importantes obtidos sobre técnicas de cultivo in vitro de café em áreas como bioquímica, fisiologia, sistemas de regeneração e engenharia genética serão apresentadas e discutidas.

Palavras-chave: Coffea, café, cultivo in vitro, embriogênese somática, regeneração, transformação genética.

\section{INTRODUCTION}

Coffee, one of the most widely traded commodities in the international markets, is an agricultural crop of significant economic importance. Coffee is grown in 80 countries around the world with $70 \%$ being produced by smallholder farmers. Besides being a source of income for millions of people, it represents a generation of foreign currency.

Out of more than 100 coffee species only two are commercial species: Coffea arabica L. (arabica type coffee) and Coffea canephora p. ex Fr. (canephora or Robusta type coffee). Arabica type coffee is typical of the highland growing regions and is responsible for almost $75 \%$ of world production while the remaining $25 \%$ is occupied by the Robusta type coffee which is grown in lowland regions.

Between these two species, Arabica coffee provides a superior beverage but is quite sensitive to different pests (fungi, nematodes, and insects), whereas Robusta coffee produces a lower quality coffee but is more resistant to pests. While it would be desirable to combine these genetic traits, traditional plant breeding techniques have been largely unsuccessful since C. arabica is tetraploid whereas the other species are diploid. On the other hand, C. canephora and other non-arabica species are self-incompatible. As a result, the transfer of genetic traits from wild outbred species of the genus to the cultivated C. arabica cultivar is quite difficult. A further complication is Coffea's lengthy period for fruit development and the bean-to-bean generation time. A breeding cycle for coffee plants takes four years, i. e., seeds to a flowering plant and back to seeds. Selections for yield are usually made from 6-8 year old coffee plants.

Several cycles of crossings and selections are required until one finds superior genotypes. In order to assure fidelity through seed propagation, six cycles of selfing are required. Considering one cycle for hybridization and selection and six cycles for seed homozygosity, a normal coffee breeding program requires 28 years. All these inconveniences make such traditional approaches costly and time consuming. Advances in plant cell culture techniques provide opportunities to shorten the time required for coffee improvement. 
Fortunately, the last decades have been eyewitness of the development of new technological tools which introduce a huge potential in plant growth improvement. In addition to the conventional growth improvement, these techniques can accelerate the release of varieties with new traits. Plant biotechnology offers several possibilities for increasing productivity, diversification and production. This technology includes plant tissue culture techniques, the use of advanced molecular biology techniques for plant transformation, genomic analysis coupled with breeding and plant-disease diagnoses. This group of new techniques has been added to the toolbox to strengthen programs in order to obtain better crops. The goal is still the same as for the traditional ones: to improve traits in a way that resulting plants attain superior agronomical traits but in a faster and efficient way.

Among factors limiting coffee production, there are the different susceptibilities to several diseases, photosynthetic efficiency, water utilization and tolerance to soil acidity and to aluminum.

Plant tissue culture has allowed a mass production of plants, increasing the capacity of plant multiplication with specific agronomical traits. It has also been a major tool for basic and practical investigation in agriculture. These new developments include clonal propagation, cell suspension culture, anther/pollen culture, embryo culture, protoplast isolation and regeneration, and the development of new interspecific plantlets in vitro. Furthermore, these in vitro techniques have allowed studies at the cellular and molecular levels making the coffee plant a "model" among the woody species. This "model plant" has much potential in molecular biology, biochemical and biotechnological research.

\section{In vitro tissue culture methods in coffee}

Plant regeneration via tissue culture should be very effective for propagation and improvement of coffee plants. Although the main goal of early studies was to establish protocols to regenerate coffee species, the development of these protocols and the recent advances made it possible to apply these techniques for the study of various other aspects.

The first requirement to regenerate a large number of plants is to obtain a large population of cells. This is accompanied by removing a small portion of the plant (an explant) and placing it in liquid or on solid medium. This medium should contain various nutrients and hormones sufficient for the cells to divide and reproduce and eventually to form a large collection of cells (suspensions if liquid medium, calli if solid medium). After an appropriate time, when this primary culture is large enough, it can be subdivided and/or transferred to another medium depending on the type of regeneration required.

Callus Cultures: Callus formation from explants is occasionally spontaneous, but generally requires an auxin in the medium, often in combination with cytokinin. The pioneer report on coffee tissue culture was done by Staritsky (1970) who used internode segments of young orthotrophic shoots as explants. He obtained fast growing callus using a modified Linsmaier and Skoog medium (1965) supplemented with sucrose $\left(30\right.$ g.L $\left.\mathrm{L}^{-1}\right)$, thiamine $\mathrm{HCl}\left(1 \mathrm{mg} . \mathrm{L}^{-1}\right)$, L-cysteine $\mathrm{HCl}$ (10 mg. $\left.\mathrm{L}^{-1}\right)$, myo-inositol (100 mg. $\left.\mathrm{L}^{-1}\right)$, kinetin $(0.1$ mg.L $\left.\mathrm{L}^{-1}\right)$, , 4-dichlorophenoxyacetic acid (2,4-D, $\left.0.1 \mathrm{mg} . \mathrm{L}^{-1}\right)$ or naphthalene acetic acid (NAA, $1 \mathrm{mg} . \mathrm{L}^{-1}$ ).

Later, Sharp et al. (1973) established callus from seeds, shoots, leaves and anthers of Coffea arabica and used the same salt medium but increased some of the organic components to establish these cultures. They found conditions (absence of illumination and a temperature of $28^{\circ} \mathrm{C}$ ) in which callus cells proliferate more efficiently. Monaco et al. (1974) obtained a rapid cell proliferation at the surface of explants from developing fruits with immature seeds of Coffea arabica and Coffea stenophylla that were grown in the dark at $25-28^{\circ} \mathrm{C}$ and in medium used by Staritsky (1970) but in the absence of 2,4-D.

They observed differences in the rate of cell proliferation and texture of cultured perisperm tissues that varied from a white friable callus to a cream colored solid callus. These early studies mentioned above were the basis for subsequent work and opened the possibility of applying these kinds of techniques in the formulation, development and improvement of procedures to induce the morphogenetic potential in other coffee species. Thereafter, Herman and Haas (1975) obtained clonal propagation of $C$. arabica from callus culture through organoid formation; and Söndahl and Sharp (1977; 1979) established conditions for formation of somatic embryos from auxin-induced leaf callus of $C$. arabica using media with different combinations of auxins and cytokinins.

Cell suspension and Protoplast Cultures: The establishment of cell suspension cultures has been used in coffee for different purposes, such as an interphase for obtaining somatic embryos, protoplast isolation, plant regeneration, etc. Although Keller et al. (1972) reported production and release of caffeine from primary callus cultures derived 
from endosperm and pericarp of C. arabica, the first coffee suspension cultures were established with the aim to study the production of aromatic compounds from cells (Townsley, 1974). Cultures were initiated from friable callus derived from orthotropic shoots of C. arabica. Later, these same suspension cultures were used to analyze caffeine and chlorogenic acid contents (Buckland and Townsley, 1975) and to compare unsaponifiable lipids in green beans with those in cell suspensions (Van der Voort and Townsley, 1975). Additional studies of caffeine synthesis and biodegradation of purine alkaloids in coffee suspension cultures were made by Frischknecht and Baumann (1980), and Baumann et al. (1983).

A number of papers have been published on various aspects of the isolation and culture of coffee protoplasts. Söndahl et al. (1980), Orozco and Schieder (1984), and Acuña and de Peña (1987) isolated protoplasts from leaf callus, leaves, and cell suspensions, respectively. In all cases, cell wall formation, cell division, and callus formation was observed but in no case did regeneration of plants occur, which complicates the production and culture of protoplasts from coffee cells. Schöpke et al. (1987) reported somatic embryogenesis and plantlet regeneration in protoplasts isolated from cell suspension-derived somatic embryos of $C$. canephora. Only some of the embryos could be regenerated to plantlets when globular embryos were subcultured on a medium devoid of growth regulators.

In other studies, Schöpke et al. (1988) and Schöpke (1989) isolated protoplasts from cell suspensions of $C$. arabica, C. canephora, C. salvatrix, and C. racemosa. In these cases, the protoplasts regenerated cell walls and a few divisions occurred, but the cells did not survive more than 10 days in culture. After these initial successes, regeneration from protoplasts of $C$. arabica was achieved by other workers. Acuña and de Peña (1991) also reported plant regeneration from protoplasts of embryogenic cell suspension of $C$. arabica Caturra. In this report, from a total of 65 somatic embryos, 35 were transferred directly to nonsterile soil in the greenhouse. They also found that the total process of regeneration of plants from protoplasts took an average of 9 to 10 months.

Spiral and Pétiard (1991) regenerated plants from protoplasts of $C$. arabica, C. canephora and from the interspecific hybrid Arabusta. Grèzes et al. (1994) optimized conditions for the isolation of protoplasts from nonembryogenic cell suspensions of $C$. arabica. They described experiments to improve the yield of viable protoplasts, by analyzing the different parameters (enzymatic treatments, plasmolysis, physiological state of the cells or temperature) influencing the release of coffee cell protoplasts. A number of viable protoplasts ranging from $3.5 \times 10^{6}$ to $4.6 \mathrm{X}$ $10^{6}$ protoplasts per gram of fresh weight was obtained corresponding to a 10 - to 15 -fold increase of the protoplast yield obtained by Acuña and de Peña (1991). Tahara et al. (1994) reported a simplified method for preparing and culturing protoplasts from embryogenic callus induced from young leaves of mature $C$. arabica trees, and subsequent formation of somatic embryos from these protoplasts with cytokinin as the only plant growth regulator.

Among the several procedures reported for the regeneration of coffee protoplasts, there are great differences, especially with regard to the growth regulators and the cultured media used. Flexibility towards growth regulators can be seen in protoplast cultures that resulted in the regeneration of plantlets. The embryogenic tissue used for protoplast isolation can be induced either by an auxin/ cytokinin mixture (Schöpke et al. 1987; Schöpke, 1989; Spiral and Pétiard, 1991) or by a cytokinin alone (Yasuda et al., 1986; Acuña and de Peña, 1991; Tahara et al., 1994). Correspondingly, the media used for protoplast culture contain an auxin/cytokinin mixture or a cytokinin, except for the medium used by Acuña and de Peña (1991) who induced embryogenic tissue with 6-benzylamino purine (BAP) alone, and then cultured protoplasts isolated from this tissue in a medium containing a mixture of 2,4-D, NAA, and kinetin.

Somatic embryogenesis: Somatic embryogenesis is a valuable tool for the clonal propagation of Coffea species and for the breeding for disease resistance, stress tolerance, lowcaffeine content, etc. Early studies have demonstrated that the presence of an auxin is critical for embryo initiation and decreasing the auxin concentration or its complete absence promoted maturation. Thus, in general terms, the established basic protocol involves culture in a primary medium with an auxin source and subculturing in a secondary medium devoid of growth regulators, both containing a substantial supply of reduced nitrogen (Ammirato, 1983).

In coffee, there are a number of reports on in vitro plant regeneration through somatic embryogenesis from stem, leaf tissues and perisperm tissue (Staritsky, 1970; Söndahl and Sharp, 1977; Dublin, 1981; Yasuda et al., 1985; de García and Menéndez, 1987; Raghuramulu et al., 1987; Neuenschwander and Baumann, 1992; Söndahl and Lauritis, 1992; Sreenath et al., 1995). The majority of culture 
media used for the induction of somatic embryogenesis in coffee contained a mixture of an auxin and a cytokinin. However, Dublin (1981) showed that it is possible to induce embryogenesis in leaf explants with a cytokinin (BAP) alone. This observation was confirmed by Yasuda et al. (1985) and Hatanaka et al. (1991), who reported that cytokinin is very important and auxins have inhibitory effects towards Coffea somatic embryogenesis.

Yasuda et al. (1995) established somatic embryogenesis in C. arabica and C. canephora from leaf explants of mature trees using cytokinin as a sole plant hormone. Both species reacted in different ways. In C. canephora, somatic embryos formed from the cut edges of cultured young leaf explants in contact with cytokinin of the medium. Addition of auxin with cytokinin inhibited embryo formation. Somatic embryos were grown to young plants on the cytokinin medium. In arabica, embryogenic callus was induced after prolonged culture with cytokinin and then somatic embryos formed on the embryogenic callus.

Leaf pieces of arabusta coffee trees can be induced to form embryos directly when cultured on a basal MS medium devoid of auxin and containing high levels of cytokinin. By this means, somatic embryogenesis of coffee has been obtained in single-step (Dublin, 1981; Yasuda et al., 1985; Hatanaka et al., 1991; Yasuda et al., 1995) and doublestep procedures (Söndahl and Sharp, 1977; Dublin, 1984; Zamarripa et al., 1991; Neuenschwander and Baumann, 1992). The single-step procedure has the advantage of rapid embryo formation and high embryo germination rate. The double-step procedure yields high frequency somatic embryogenesis (HFSE) which has clear implications with regard to large scale production of somatic embryos. In addition, for some genotypes, the HFSE process may be the sole procedure for obtaining somatic embryogenesis.

High frequency somatic embryogenesis (HFSE) from coffee leaf explants was first reported by Söndahl and Sharp (1977) in C. arabica cv. Bourbon. HFSE is characterized by the abundant appearance of friable, highly embryogenic callus. The experimental procedure describes two successive media that were necessary: "the conditioning medium" and the "induction medium". Successful induction of high frequency embryogenic calluses was found to be dependent on the 2,4-D and kinetin concentrations in the first medium (conditioning medium).

The specific nature of HFSE-callus permits its use in liquid culture systems. Neuenschwander and Baumann (1992) described a protocol for somatic embryogenesis in liquid culture. They proposed the term self-controlled somatic embryogenesis (SCSE) because the new somatic embryos germinated at a rate of $94.5 \%$ without the need of a maturation step. Yields and germination rates of HFSE were markedly lower as compared to SCSE. The production of somatic embryos in liquid medium has been applied as an approach for a rapid mass propagation of coffee plants (Zamarripa et al., 1991; Ducos et al., 1993; Noriega and Söndahl, 1993; van Boxtel and Berthouly, 1996).

Zamarripa et al. (1991) reported that the production of somatic embryos is highly dependent on the inoculum density, the production and development of embryos being inhibited when the inoculum density is high. This inhibition is partially suppressed when the medium is periodically renewed. At a low inoculum density of $1 \mathrm{~g} \mathrm{FW.L-1,} \mathrm{460,000}$ embryos were produced in 7 weeks in Erlenmeyer flasks; in a bioreactor, the production was about 4,000 embryos per liter per day. Ducos et al. (1993) achieved 600,000 coffee somatic embryos per liter using a stirred bioreactor, and Zamarripa (1993) described the feasibility of scale-up of somatic embryogenesis in C. canephora and Arabusta reporting yields of 400-500 x $10^{3}$ embryos after 7 weeks. The plantlet regeneration capacity was measured. Starting with $1 \mathrm{~g}$ of callus per liter of medium, 56,000 plantlets could be regenerated (Ducos et al., 1999).

Berthouly et al. (1995) and Etienne et al. (1997) have developed a somatic embryo mass production system using a temporary immersion bioreactor. This system includes the use of immersion techniques with specially adapted culture vessels $\left(\right.$ RITA $\left.^{\mathrm{R}}\right)$ which allows the direct regeneration, in the same container and without subculture, of plantlets from cell suspensions. They obtained a high frequency of embryogenic tissues, cell suspensions and regeneration of plants. Using germinated somatic embryos of Coffea arabica, direct sowing resulted in a highly successful conversion of embryos into plants. A culture density above 1600 embryos per liter in a bioreactor positively affected embryo morphology by causing higher embryonic axis elongation (Barry-Etienne et al., 1999). Such embryos showed better plant conversion rates after direct sowing in the nursery.

Nevertheless, during the first months in the nursery, the plantlets derived from embryos produced under temporary immersion exhibited a low and slow growth when compared to seedlings (Barry-Etienne et al., 2002). Recently, mass regeneration of $C$. arabica $\mathrm{L}$. somatic embryos using a temporary immersion bioreactor was improved by optimizing the immersion cycles. It was demonstrated that increasing 
the frequency of short immersions (1 $\mathrm{min}$ immersions every 24, 12 and $4 \mathrm{~h}$ ) stimulated embryo production (480, 2092 and 3081 embryos per liter bioreactor, respectively) and improved quality $(60,79$ and $85 \%$ of torpedo-shaped embryos, respectively) (Albarrán et al., 2005).

Direct embryogenesis can be induced on certain explants. Direct somatic embryogenesis is the formation of somatic embryos from the explant without the formation of an intermediate callus phase (Raghavan and Sharma, 1995). In most plants, direct somatic embryogenesis is difficult to obtain. Loyola-Vargas et al. (1999) have reported direct somatic embryogenesis from explants of leaves in Coffea arabica and it was supported by histological evidence. They modified the protocol described by Yasuda et al. (1985). Browning of the tissues, caused by an excessive accumulation of phenolic compounds, is necessary for the somatic embryogenesis process in coffee (Quiroz-Figueroa et al., 2002). Similar observations have been reported by other authors (de García and Menéndez, 1987; Neuenschwander and Baumann, 1992; van Boxtel and Berthouly, 1996; Menéndez-Yuffá and de García, 1997).

Somatic embryogenesis in coffee has been the subject of several histological studies (Söndahl et al., 1979a, b; Nassuth et al., 1980; Michaux-Ferrière et al., 1987, 1989; Nakamura et al., 1992; Tahara et al., 1995; Menéndez-Yuffá and de García, 1997; Quiroz-Figueroa et al., 2002). Histogenesis of indirect somatic embryogenesis of $C$. arabica has been described by Söndahl et al (1979a); they demonstrated that callus proliferation, in which some of the cells differentiate and develop into embryos, originated from spongy mesophyll cells. Nassuth et al. (1980) observed that all parenchymatic tissues between epidermis and vascular cambium were capable of being transformed into callus tissue, the cortex being the most active layer in this respect. After 14 days of culture, proembryos were observed in the zone of callus formation. Scanning electron microscopy observations (Söndahl et al., 1979b; Nakamura et al., 1992) revealed very young embryos with a mixture of rounded, elongated or curled cells of the explant.

While these studies have provided valuable information, they did not clearly demonstrate embryo development from one single cell to the final stages. Michaux Ferrière et al. (1989), and Menéndez-Yuffá and de García (1997) provided evidence for the hypothesis that somatic embryos in Coffea have unicellular origins. In both reports, the main stages of ontogenesis were not observed. Quiroz-Figueroa et al. (2002) demonstrated that the sequential events in embryo development arise through symmetric unicellular pathways. They concluded, on basis of their histological observations, that both direct and indirect somatic embryos of coffee formed on explanted leaf segments and callus, respectively, have a unicellular origin.

\section{Physiological and biochemical advances}

Coffee, as one of the most important major economic crops in the world, has been the subject of extensive research related to genetic improvement aimed at increasing yield. On the other hand, knowledge about the physiological and biochemical processes involved is scarce. The few studies carried out in this area can be resumed in three topics: the biosynthetic pathway of theobromine and caffeine, the changes during somatic embryogenesis, and the toxicity of aluminum on in vitro coffee cultures. Therefore, in order to enlarge our perception of basic scientific knowledge and to understand different mechanisms at the cellular and molecular level it is imperative that new research fields be opened up on these subjects.

Early studies related to the purine alkaloid (PA) production and metabolism in in vitro cultures of Coffea spp., including $C$. arabica, have been reported (Baumann and Frischknecht, 1988). Cell cultures of coffee were obtained which maintained the ability to produce caffeine and theobromine and to release these purine alkaloids into the medium (Keller et al., 1972; Waller et al., 1983). Besides PA, sterols, fatty acids, chlorogenic acids, and coffee aromatics were also produced (Townsley, 1974; Van de Voort and Townsley, 1975; Buckland and Townsley, 1975). Furuya et al. (1990) have demonstrated that a polyurethane foam cube was eventually capable of immobilizing more than 10 $\mathrm{g}$ (fresh weight) of coffee cells in long-term culture. Coffee cells in suspension culture were capable of biotransforming theobromine to caffeine (Furuya et al., 1991).

Based on recent knowledge of enzymology and molecular biology, it was proposed that caffeine is synthesized through multiple methylation of xanthine derivatives (Ashihara and Crozier, 2001). Enzymatic activities of N-methyltransferase for caffeine biosynthesis in coffee plants have been detected in cell-free extracts prepared from cultured cells (Baumann et al., 1983). N-methyltransferase proteins have also been purified (Mazzafera et al., 1994; Mösli Waldhauser et al., 1997; Moisyadi et al., 1998). Subsequently, cDNAs for 7methylxanthine methyltransferase (MXMT or theobromine synthase) were successfully cloned from coffee plants (Ogawa et al., 2001; Mizuno et al., 2003). 
Several studies have been reported concerning the modification of the embryogenic response in Coffea spp. Somatic embryogenesis of $C$. arabica was induced by the nitrogen source. The optimum nitrogen concentrations were between 3.75 and $15 \mathrm{mmol} . \mathrm{L}^{-1}$ nitrogen with a nitrate/ ammonium molar ratio of 2:1 or 1:2 (Fuentes-Cerda et al., 2001). Also, the use of salicylic acid had a positive effect on cellular growth and somatic embryogenesis, causing a twofold increase in both processes (Quiroz-Figueroa et al., 2001). The protein electrophoretic patterns during embryogenesis in C. arabica were determined and revealed qualitative and quantitative differences in size and charge (Menéndez-Yuffá et al., 1994). The two-dimensional analysis of embryogenic calli revealed seven characteristic polypeptides with a molecular weight of 23 to $35 \mathrm{kDa}$ in a broad pI from acid to basic. Five of them were found in the neutral to acid pI. In the nonembryogenic calli, seven distinctive polypeptides were present in the range of 15 to $70 \mathrm{kDa}$. Four of the polypeptides were acidic, three of $70 \mathrm{kDa}$ and one of $15 \mathrm{kDa}$. However, the identification and properties of these proteins remains to be determined in order to understand their role in somatic embryogenesis.

In some tropical soils, heavy metal toxicity causes reduced growth and yield losses. Coffee plantations are mainly confined to acid soils, where several toxic forms of aluminum (Al) are present. Using as a model suspensions of C. arabica cells (Martínez-Estévez et al., 2001a), and in view of the suggestion that $\mathrm{Al}$ disrupts the metabolism of membrane phospholipids, the effect of $\mathrm{AlCl}_{3}$ on different components of this pathway has been studied. When suspension cells were incubated with increasing concentrations of $\mathrm{AlCl}_{3}$ (200-1000 umol. $\left.\mathrm{L}^{-1}\right)$, the protein phosphorylation pattern changed. The phosphorylated proteins with a molecular mass of 18,31 and $53 \mathrm{kDa}$ increased dramatically after in vivo treatment of cells with $\mathrm{AlCl}_{3}$. When $\mathrm{AlCl}_{3}$ was added to an in vitro phosphorylation reaction, no differences in phosphorylation were observed (Martínez-Estévez et al., 2001b). These results suggested that in vivo treatment of Coffea cells with $\mathrm{AlCl}_{3}$ affects the activity of some protein kinases. The effect of $\mathrm{Al}$ on phosphoinositide-specific phospholipase $\mathrm{C}$ (PLC) and lipid kinase activities also was examined (Martínez-Estévez et al., 2003). Two main effects were seen when cells were treated with $\mathrm{AlCl}_{3}$. In periods as short as $1 \mathrm{~min}, \mathrm{Al}$-exposed cells increased their activity of PLC. Over longer periods, PLC activity was inhibited by more than $50 \%$. The activity of phosphatidylinositol 4-kinase, phosphatidylinositol phosphate 5-kinase and diacylglycerol kinase increased when cells were incubated in the presence of different concentrations of $\mathrm{AlCl}_{3}$. These reports strongly support the hypothesis that $\mathrm{Al}$ disrupts the metabolism of membrane phospholipids regulating not only PLC but also other enzymes that have key roles in signal transduction pathways. Despite the research done in this field, we still need to understand the biochemical and molecular basis of Al-toxicity in coffee. This becomes particularly important for some countries like Brazil where acid soils are a major problem for coffee productivity.

\section{Transformation of coffee}

To establish a genetic transformation system a competent explant is required for the transformation process, together with an in vitro culture system that permits a high frequency of regeneration. Furthermore, a system for genic transfer is required that is simple, cheap, and reproducible. In coffee, there are efficient regeneration systems through somatic embryogenesis from several tissues and the genetic transformation of coffee plants has been achieved successfully by several research groups (Barton et al., 1991; Spiral et al., 1993; Sugiyama et al., 1995; van Boxtel et al., 1995; Hatanaka et al., 1999; Spiral et al., 1999; Leroy et al., 2000; Fernández-Da Silva and Menéndez-Yuffá, 2003; Ogita et al., 2004).

Several studies in coffee have indicated that some in vitro tissue cultures of coffee showed tolerance to high kanamycin concentrations (400 mg.L ${ }^{-1}$ ) (Spiral et al., 1993; Giménez et al., 1996). In order to develop a selective growth system for genetically transformed coffee tissues, van Boxtel et al. (1997), studied the effects of the selective agents chlorsulfuron, glufosinate, glyphosate, hygromycin, and kanamycin on callus development from leaf explants and embryogenic suspension cultures. Chlorsulfuron and hygromycin caused strong inhibition and severe necrosis, whereas glyphosate and kanamycin showed variable inhibition. Glufosinate appeared to efficiently inhibit growth of both leaf callus and callus suspensions of all genotypes tested without inducing necrosis, indicating their potential for the detection of stably transformed coffee tissues.

Two kinds of transformation techniques have been tested: the indirect Agrobacterium-mediated transformation (which is the technique currently used to transfer genes in coffee plants) and direct transformation, through particle bombardment and electroporation of tissues.

Indirect gene transfer: Ocampo and Manzanera (1991), using wild-type Agrobacterium strains, observed the production of tumors on infected hypocotyls of in vitro germinated coffee 
seeds. Spiral and Pétiard (1991) obtained preliminary results using protoplast co-culture with different Agrobacterium strains carrying neomycine phosphotransferase (NPTII) and $\beta$-glucuronidase (GUS) marker genes under control of the CaMV35S promoter. They observed transient expression by GUS histochemical assay on callus tissue derived from the treated protoplast.

Transformed plantlets of Coffea canephora were obtained by regeneration of somatic embryos infected with Agrobacterium rhizogenes. Integration of NPTII and GUS genes were demonstrated by polymerase chain reaction (PCR) and $\beta$-glucuronidase assay (Spiral et al., 1993). Sugiyama et al. (1995), after transforming Coffea arabica using the Ri plasmid of Agrobacterium rhizogenes strain IFO 14554, suggested that this kind of transformation is applicable to the production of plantlets with a phenotype of foreign genes.

The production of transgenic plants by cocultivating somatic embryos of $C$. canephora with A. rhizogenes (A4) and disarmed A. tumefaciens (LBA4404) was reported by Leroy et al., (1997). Hatanaka et al. (1999) reported the successful genetic transformation of C. canephora using A. tumefaciens EHA101 harboring pIG121-Hm from embryogenic calli. Somatic embryos were germinated and regenerated to small plantlets which were then transferred to medium containing both $100 \mathrm{mg} . \mathrm{L}^{-1}$ hygromycin and 100 mg. $\mathrm{L}^{-1}$ kanamycin for final selection of transgenic plants. The selected plantlets exhibited strong GUS activity in leaves and roots. Furthermore, the GUS and hygromycin phosphotransferase (HPT) genes were confirmed to be stably integrated into the genome of the coffee plants by PCR.

Leroy et al. $(1999 ; 2000)$ reported the first transformation of coffee plants containing a Bacillus thuringiensis gene which had been integrated into the coffee genome. A synthetic gene encoding for a $B$. thuringiensis CrylAc endotoxin, which is active against the coffee leaf miner Perileucoptera coffeela, was introduced into three genotypes of the two cultivated species, C. arabica and C. canephora, conferring insect resistance. Somatic embryos were co-cultivated with the LBA4404 strain of Agrobacterium tumefaciens containing the $\operatorname{cry} 1 \mathrm{Ac}$ gene. More than 100 transformed plants from independent transformation events were obtained for each coffee genotype. The integration and expression of the cry $1 \mathrm{AC}$ gene was studied by western blotting analyses. Transgenic plants demonstrated effective resistance to leaf miner bioassays with the insects.
Direct gene transfer: The first genetic transformation of coffee cells reported was by protoplast electroporation. Barton et al. (1991) obtained plantlets of Coffea arabica genetically altered. They established suspension cultures to obtain protoplasts which were transformed with a kanamycinresistance gene by an electroporation procedure. Embryos were formed from transformed cells and regenerated into plantlets. The regenerated embryos contained the inserted foreign DNA. However, the transformed coffee plantlets established feeble root systems and therefore did not develop into plants capable of flowering.

The application of the biobalistic system with coffee tissues was described for the first time by van Boxtel et al. (1995). The experiments were carried out on different tissues and revealed that suspension cultures and somatic embryos were less appropriate for transient expression studies of $\beta$-glucuronidase. Transient expression was most easily detectable and most frequently observed with bombarded leaves of microcuttings. Among four (CaMV-E35S, LTR, UBQ1, and EFo-A1) tested promoters controlling GUS expression, the best results with coffee were obtained using the EF $\alpha-\mathrm{A} 1$ promoter of $A$. thaliana.

Fernández-Da Silva and Menéndez-Yuffá (2003) developed a method for coffee genetic transformation by electroporation. They evaluated different electroporation conditions on different plant tissues like embryogenic calli, leaf sections from in vitro plants, and somatic embryos at globular and torpedo stages obtained from cell suspensions. The optimal conditions for electroporation were one hour of enzymatic pretreatment of torpedo-shaped embryos, electroporation at $375 \mathrm{~V}$ and $900 \mu \mathrm{F}$. The secondary somatic embryos regenerated from electroporated torpedo-shaped somatic embryos were positive for gus expression, and also in the PCR analysis for the genes gus and bar.

Genetic Engineering: Genetic engineering of coffee has focused on seed production, ripening, insect control, and reduced caffeine. The decaffeination process is carried out by supercritical extraction that involves washing the beans with liquid carbon dioxide. The procedure is not only expensive but it also removes other compounds that give coffee its rich taste and aroma. Recently, an advance in transgenic plant research of coffee has been achieved: coffee plants (Coffea arabica and Coffea canephora) have been genetically modified to contain less caffeine (Ogita et al., 2003; 2004). The expression of the gene encoding theobromine synthase (CaMXMT1) was repressed by RNA interference 
(RNAi). These reports provide evidence for the successful production of a low-caffeine phenotype in both 'Arabica' and 'Robusta' coffee species, with 100\% decaffeination in embryogenic tissues and $70 \%$ in plantlets, respectively. The 3'-untranslated region and coding region of CaMXMT1 cDNA were selected for design of double-stranded RNAi constructs. Agrobacterium tumefaciens EHA101 cells were transfected with these constructs and then used to transform embryogenic tissues of $C$. arabica and somatic embryos of C. arabica and C. canephora.

After 2-4 months of culture, most infected tissues turned brown and necrotic, however it was possible to regenerate hygromycin-resistant cells from these tissues. Seedlings were then cultured. Young leaves of one-year-old seedlings were collected 2-3 weeks after sprouting and their purine alkaloid content was measured. The wild type and transgenic lines that expressed green fluorescent protein (GFP) contained similar amounts of endogenous theobromine and caffeine (about 1 and $8.4 \mathrm{mg}$ per $\mathrm{g}$ of fresh leaf tissue, respectively). In contrast, young leaves of transgenic lines, expressing RNAi showed a 40-70\% reduction in theobromine content and a 50-70 \% reduction in caffeine. At maturity, these transgenic plants should produce essentially normal coffee beans with low caffeine content. These decaffeinated coffee plants will, in theory, bring an end to the expensive, industrial decaffeination that results in a loss of flavour.

\section{CONCLUSION}

In the last few years, interest has grown in coffee as a model to study some very challenging aspects of modern biology, such as plant transformation and regeneration. Although coffee is the world's most heavily traded commodity apart from oil, research into some of the basic biological topics has indeed been neglected. The aim of this review was to point out the importance of developments in in vitro cell culture, somatic embryogenesis, plant regeneration and transformation in coffee, as well as call attention to some of the few biochemical and molecular studies that have been carried out.

Research on coffee harvesting, processing, pest and disease control, pathogen interaction, and abiotic stress is essential for the continued production of a high-quality coffee. Progress in our knowledge and understanding of the biochemical and molecular basis of the topics mentioned above can only come through continued research. This is the key to success in the quest for improving the yield and quality of this economically important crop, that would bring enormous benefits to both producers and consumers.
Acknowledgements: We would like to thank Ligia BritoArgáez and J. Armando Muñoz-Sánchez for their contribution in the experiments for the Hernández-Sotomayor's Laboratory whose work is funded by a grant $45798-Z$ from CONACYT.

\section{REFERENCES}

Acuña JR, de Peña M (1987) Isolation and culture of coffee protoplasts. In: Abstr Int. Congr. Plant Tissue Cult., Tropical Species, Bogotá, Colombia, pp.34-35.

Acuña JR, de Peña M (1991) Plant regeneration from protoplasts of embryogenic cell suspensions of Coffea arabica L. cv caturra. Plant Cell Rep. 10:345-348.

Albarrán J, Bertrand B, Lartaud M, Etienne H (2005) Cycle characteristics in a temporary immersion bioreactor affect regeneration, morphology, water and mineral status of coffee (Coffea arabica) somatic embryos. Plant Cell Tissue Organ Cult. 81:27-36.

Ammirato PV (1983) Embryogenesis. In: Evance DA, Sharp WR, Ammirato PV, Yamada Y (eds), Handbook of Tissue Culture, Vol. 1, pp.82-123. Macmillian, New York.

Ashihara H, Crozier A (2001) Caffeine: a well known but little mentioned compound in plant science. Trends Plant Sci. 6(9):407-413.

Barry-Etienne D, Bertrand B, Vasquez N, Etienne H (1999) Direct sowing of Coffea arabica somatic embryos massproduced in a bioreactor and regeneration of plants. Plant Cell Rep. 19:111-117.

Barry-Etienne D, Bertrand B, Schlönvoigt A, Etienne H (2002) The morphological variability within a population of coffee somatic embryos produced in a bioreactor affects the regeneration and the development of plants in the nursery. Plant Cell Tissue Organ Cult. 68:153-162.

Barton CR, Adams TL, Zarowitz MA (1991) Stable transformation of foreign DNA into Coffea arabica plants. In: Proc. XIV Colloq. Sci. Int. Coffee. San Francisco, pp.460-464.

Baumann TW, Koetz R, Morath P (1983) N-methyltransferase activities in suspension cultures of Coffea arabica L. Plant Cell Rep. 2:33-35.

Baumann TW, Frischknecht PM (1988) Caffeine: Production by plant (Coffea spp) Cell Cultures. In: Bajaj YPS (ed), Biotechnology in Agriculture and Forestry, pp.264-281. Springer-Verlag, Berlin.

Berthouly M, Dufour M, Alvard D, Carasco C, Alemanno L, Teisson C (1995) Coffee micropropagation in a liquid medium using the temporary immersion technique. In: XVI Colloq. Sci. Int. Coffee. Kyoto, pp.514-519.

Buckland E, Townsley PM (1975) Coffee cell suspension cultures. Caffeine and chlorogenic acid content. Journal de l'Institut Canadien des Sciences et Technologies d'Alimentation 8:164-165.

Dublin P (1981) Embroyogenèse somatique directe sur fragments de feuilles de caféier Arabusta. Café Cacao Thé 25: 237-242.

Dublin P (1984) Techniques de reproduction végétative in vitro et amélioration génétique chez les caféiers cultivés. Café Cacao Thé 28:231-244. 
Ducos JP, Zamarripa A, Eskes A, Pétiard V (1993) Production of somatic embryos of coffee in a bioreactor. In: XV Colloq. Sci. Int. Coffee. Montpellier, pp.89-96.

Ducos JP, Gianforcaro M, Florin B, Pétiard V, Deshayes A (1999) A technically and economically attractive way to propagate elite Coffea canephora (Robusta) clones: in vitro somatic embryogenesis. In: XVIII Colloq. Sci. Int. Coffee. Helsinki, pp.295-301.

Etienne H, Bertrand B, Anthony F, Côte F, Berthouly M (1997) L'embryogenèse somatique: un outil pour l'amélioration génétique du caféier. In: XVII Colloq. Sci. Int. Coffee. Montreux, pp.457-465.

Fernández-Da Silva R, Menéndez-Yuffá A (2003) Transient gene expresion expression in secondary somatic embryos from coffee tissues electroporated with the genes gus and bar. Electr. J. Biotechnol. 6:29-38.

Frischknecht PM, and Baumann TW (1980) The pattern of purine alkaloid formation in suspension cultures of Coffea arabica. Planta Medica 31:344-350.

Fuentes-Cerda CFJ, Monforte-González M, Méndez-Zeel M, Rojas-Herrera R, Loyola-Vargas R (2001) Modification of the embryogenic response of Coffea arabica by the nitrogen source. Biotechnol. Lett. 23:1341-1343.

Furuya T, Koge K, Orihara Y (1990) Long term culture and caffeine production of immobilized coffee (Coffea arabica) L. cells in polyurethane foam. Plant Cell Rep. 9:125-128.

Furuya T, Orihara Y, Koge K (1991) Biotransformation of theobromine to caffeine in suspension and polyurethane foam immobilized coffee (Coffea arabica L.) cells. Plant Cell Rep. 9:659-662.

García E de, Menéndez A (1987) Embriogénesis a partir de explantes foliares del cafeto catimor. Café Cacao Thé 31 (1):15-22.

Giménez CA, Menéndez-Yuffá A, de García E (1996) Efecto del antibiótico kanamicina sobre diferentes explantes del híbrido de café (Coffea sp) Catimor. Phyton 59:39-46.

Grèzes J, Thomas D, Tomasset B (1994) Factors influencing protoplast isolation from Coffea arabica cells. Plant Cell Tissue Organ Cult. 36:91-97.

Hatanaka T, Arakawa T, Yasuda T, Uchida N, Yamaguchi T (1991) Effect of plant growth regulators on somatic embryogenesis in leaf cultures of Coffea canephora. Plant Cell Rep. 10:179-182.

Hatanaka T, Choi YE, Kusano T, Sano H (1999) Transgenic plants of coffee Coffea canephora from embryogenic callus via Agrobacterium tumefaciens-mediated transformation. Plant Cell Rep. 19:106-110.

Herman EB, Haas GJ (1975) Clonal Propagation of Coffea arabica L. from Callus Culture. Hortscience 10:588-589.

Keller H, Wanner H, Baumann TW (1972) Kaffeinsynthese in Fruchten und Gewebekulturen von Coffea arabica. Planta 108:339-350.

Leroy T, Royer M, Paillard M, Berthouly M, Spiral J, Tessereau S, Legavre T, Altosaar I (1997) Introduction de genes d'intérêt agronomique dans l'espèce Coffea canephora Pierre par transformation avec Agrobacterium sp. In: XVII Colloq. Sci. Int. Coffee. Nairobi, pp.439-446.
Leroy T, Philippe R, Royer M, Frutos R, Duris D, Dufour M, Jourdan I, Lacombe C, Fenouillet C (1999) Genetically modified coffee trees for resistance to coffee leaf miner. Analysis of gene expression, resistance to insects and agronomic value. In: XVIII Colloq. Sci. Int. Coffee. Helsinki, pp.332-338.

Leroy T, Henry AM, Royer M, Altosaar I, Frutos R, Duris D, Philippe R (2000) Genetically modified coffee plants expressing the Bacillus thuringiensis cry 1 Ac gene for resistance to leaf miner. Plant Cell Rep. 19:382-389.

Linsmaier M and Skoog F (1965) Organic Growth Factor Requirements of Tobacco Tissue Cultures. Physiol. Plant. 18: 100-127.

Loyola-Vargas VM, Fuentes-Cerda CFJ, Monforte-González M, Méndez-Zeel M, Rojas-Herrera R, Mijangos-Cortés J (1999) Coffee tissue culture as a new model for the study of somaclonal variation. In: XVIII Colloq. Sci. Int. Coffee. Helsinki, pp.302-307.

Martínez-Estévez M, Muñoz-Sánchez JA, Loyola-Vargas VM, Hernández-Sotomayor SMT (2001a) Modification of the culture medium to produce aluminum toxicity in cell suspensions of coffee (Coffea arabica L.). Plant Cell Rep. 20:469-474.

Martínez-Estévez M, Loyola-Vargas VM, HernándezSotomayor SMT (2001b) Aluminum increases phosphorylation of particular proteins in cellular suspension cultures of coffee (Coffea arabica). J. Plant Physiol. 158: 1375-1379.

Martínez-Estévez M, Racagni-Di Palma G, Muñoz-Sánchez JA, Brito-Argáez L, Loyola-Vargas VM, HernándezSotomayor SMT (2003) Aluminium differentially modifies lipid metabolism from the phosphoinositides pathway in Coffea arabica cells. J. Plant Physiol. 160:1297-1303.

Mazzafera P, Wingsle G, Olsson O, Sandberg G (1994) S-adenosyl-L-methionine: theobromine 1-N-methyltransferase, an enzyme catalyzing the synthesis of caffeine in coffee. Phytochemistry 37:1577-1584.

Menéndez-Yuffá A, de García EG, Segura-Nieto M (1994) Comparative study of protein electrophoretic patterns during embryogenesis in Coffea arabica cv Catimor. Plant Cell Rep. 13:197-202.

Menéndez-Yuffá A, de García EG (1997) Morphogenic events during indirect somatic embryogenesis in coffee "Catimor". Protoplasma 199:208-214.

Michaux-Ferrière N, Dublin P, Schwendiman J (1987) Étude histologique de l'embryogenèse somatique à partir d'explants foliaires de Coffea arabica L. Café Cacao Thé 31:103-111.

Michaux-Ferrière N, Bieysse D, Alvard D, Dublin P (1989) Étude histologique de l'embryogenése somatique chez Coffea arabica, induite par culture sur milieux uniques de fragments foliaires de génotypes différents. Café Cacao Thé 33:207-217.

Mizuno k, Okuda A, Kato M, Yoneyama N, Tanaka H, Ashihara H, Fujimura T (2003) Isolation of a new dual-functional caffeine synthase gene encoding an enzyme for the conversion of 7-methylxanthine to caffeine from coffee (Coffea arabica L.) FEBS Lett. 534:75-81. 
Moisyadi S, Neupane KR, Stiles JI (1998) Cloning and characterization of a cDNA encoding xanthosine-N ${ }^{7}$-methyltransferase from coffee (Coffea arabica). Acta Hortic. 461: 367-377.

Monaco LC, Medina H, Söndahl MR (1974) Perisperm culture of coffee. Ciência e Cultura 26:240.

Mösli Waldhauser SS, Gillies FM, Crozier A, Baumann TW (1997) Separation of N-7 methyltransferase, the key enzyme in caffeine biosynthesis. Phytochemistry 45:1407-1414.

Nakamura T, Taniguchi T, Maeda E (1992) Studies on somatic embryogenesis of coffee by scanning electron microscope. Jpn. J. Crop Sci. 61:476-486.

Nassuth A, Wormer TM, Bouman F, Staritsky G (1980) The histogenesis of callus in Coffea canephora stem explants and the discovery of early embryoid initiation. Acta Bot. Neerl. 29:49-54.

Neuenschwander B, Baumann TW (1992) A novel type of somatic embryogenesis in Coffea arabica. Plant Cell Rep. 10:608-612.

Noriega C, Söndahl M (1993) Arabica coffee micropropagation through somatic embryogenesis via bioreactors. In: XV Colloq. Sci. Int. Coffee. Montpellier, pp.73-81.

Ocampo CA, Manzanera LM (1991) Advances in genetic manipulation of the coffee plant. In: XIV Colloq. Sci. Int. Coffee. San Francisco, pp.378-382.

Ogawa M, Herai Y, Koizumi N, Kusano T, Sano H (2001) 7 Methylxanthine methyltransferase of coffee plants. J. Biol. Chem. 276:8213-8218.

Ogita S, Uefuji H, Yamaguchi Y, Koizumi N, Sano H (2003) Producing decaffeinated coffee plants. Nature 423:823.

Ogita S, Uefuji H, Morimoto M, Sano H (2004) Application of RNAi to confirm theobromine as the major intermediate for caffeine biosynthesis in coffee plants with potential for construction of decaffeinated varieties. Plant Mol. Biol. 54:931-941.

Orozco FJ, Schieder O (1984) Isolation of mesophyll protoplasts of the genus Coffea. Turrialba 34:534-536.

Quiroz-Figueroa F, Méndez-Zeel, Larqué-Saavedra A, Loyola-Vargas VM (2001) Picomolar concentrations of salicylates induce cellular growth and enhance somatic embryogenesis in Coffea arabica tissue culture. Plant Cell Rep. 20:679-684.

Quiroz-Figueroa FR, Fuentes-Cerda CFJ, Rojas-Herrera R, and Loyola-Vargas VM (2002) Histological studies on the developmental stages and differentiation of two different somatic embryogenesis systems of Coffea arabica. Plant Cell Rep. 20:1141-1149.

Raghavan V, Sharma KK (1995) Zygotic embryogenesis in gymnosperms and angiosperms. In: Thorpe TA (ed), In vitro embryogenesis in plants, pp.73-115. Kluwer Academic press, The Netherlands.

Raghuramulu Y, Purushotham K, Sreenivasan MS, Ramaiah PK (1987) In vitro regeneration of coffee plantlets in India. J. Coffee Res. 17:57-64.

Schöpke C, Müller LE, Kohlenbach HW (1987) Somatic embryogenesis and regeneration of plantlets in protoplast cultures from somatic embryos of coffee (Coffea canephora $\mathrm{P}$. ex. Fr.). Plant Cell Tissue Organ Cult. 8:243-248.
Schöpke C, Müller LE, Kohlenbach HW (1988) Coffee protoplasts: isolation, culture and plantlet regeneration. In: Proc. XII Colloq. Sci. Int. Coffee. Montreux, pp.426-432.

Schöpke C (1989) In vitro-Kultur bei Kaffee: Versuche zur Isolierung und Kultivierung von Protoplasten und zur Regeneration von Pflanzen. Maraun Frankfurt, JW Goethe Univ., $\mathrm{PhD}$ thesis.

Sharp WR, Caldas LS, Crocomo OJ, Monaco LC, Carvalho A (1973) Production of Coffea arabica callus of three ploidy levels and subsequent morphogenesis. Phyton 31:67-74.

Söndhal MR, Sharp WR (1977) High frequency induction of somatic embryos in cultured leaf explants of Coffea arabica L. Z. Pflanzenphysiol. 81:395-408.

Söndhal MR, Sharp WR (1979) Research in Coffea spp. and applications of tissue culture methods. In: Sharp WR, Larsen PO, Paddock EF, Raghavan V (eds), Plant cell and tissue culture, pp.527-584. Ohio State Univ. Press, Columbus.

Söndahl MR, Spahlinger DA, Sharp WR (1979 a) A histological study of high frequency and low frequency induction of somatic embryos in cultured leaf explants of Coffea arabica L. Z. Pflanzenphysiol. 94:101-108.

Söndahl MR, Salisbury JL, Sharp WR (1979b) SEM Characterization of embryogenic tissue and globular embryos during high frequency somatic embryogenesis in coffee callus cells. Z. Pflanzenphysiol. 94:185-188

Söndhal MR, Chapman M, Sharp WR (1980) Protoplast liberation, cell wall reconstitution, and callus proliferation in Coffea arabica L. callus tissues. Turrialba. 30:161-165.

Söndhal MR, Lauritis JA (1992) Coffee. In: Por FA, Hammerschlag F, Litz RE (eds), Biotechnology of perennial fruit crops, pp.401-420. CAB International, London.

Spiral J, Pétiard V (1991) Protoplast culture and regeneration in Coffea species. In: Proc. XIV Colloq. Sci. Int. Coffee. San Francisco, pp.383-391.

Spiral J, Thierry C, Paillard M, Pétiard V (1993) Regeneration of plantlets of Coffea canephora Pierre (Robusta) transformed by Agrobacterium rhizogenes. C.R. Acad. Sci. t316 Série III, pp.1-6.

Spiral J, Leroy T, Paillard M, Pétiard V (1999) Transgenic coffee (Coffea species). In: Bajaj YPS (ed), Biotechnology in agriculture and forestry, Vol. 44, pp.55-76. Springer-Verlag, Berlin.

Sreenath HL, Shanta HM, Babu KH, Naidu MM (1995) Somatic embryogenesis from integument (perisperm) cultures of coffee. Plant Cell Rep. 14:670-673.

Staritsky G (1970) Embryoid formation in callus tissues of coffee. Acta Bot. Neerl. 19:509-514.

Sugiyama M, Matsuoka C, Takagi T (1995) Transformation of coffee with Agrobacterium rhizogenes. In: XVI Colloq. Sci. Int. Coffee. Kyoto, pp.853-859.

Tahara M, Yasuda T, Uchida N, Yamaguchi T (1994) Formation of somatic embryos from protoplasts of Coffea arabica L. Hortscience 29:172-174.

Tahara M, Nakanishi T, Yasuda T, Yamaguchi T (1995) Histological and biological aspects in somatic embryogenesis of Coffea arabica. In: XVI Colloq. Sci. Int. Coffee. Kyoto, pp.860-867. 
Townsley PM (1974) Production of coffee from plant cell suspension cultures. Journal de l'Institut Canadien des Sciences et Technologies d'Alimentation 7:79-81.

van Boxtel J, Berthouly M, Carasco C, Dufour M, Eskes A (1995) Transient expression of $\beta$-glucuronidase following biolistic delivery of foreign DNA into coffee tissues. Plant Cell Rep. 14:748-752.

van Boxtel J, Berthouly M (1996) High frequency somatic embryogenesis from coffee leaves. Plant Cell Tissue Organ Cult. 44:7-17.

van Boxtel J, Eskes A, Berthouly M (1997) Glufosinate as an efficient inhibitor of callus proliferation in coffee tissue. In vitro Cell. Dev. Biol. - Plant 33:6-12.

Van der Voort F, Townsley PM (1975) A comparison of the unsaponificable lipids isolated from coffee cell cultures and from green-coffee beans. Journal de l'Institut Canadien des Sciences et Technologies d'Alimentation 8: 199-201.

Waller GR, Macvean CD, Suzuki T (1983) High production of caffeine and related enzyme activities in callus cultures of Coffea arabica L. Plant Cell Rep. 2:109-112.
Yasuda T, Fujii Y, Yamaguchi T (1985) Embryogenic callus induction from Coffea arabica leaf explants by benzyladenine. Plant Cell Physiol. 26:595-597.

Yasuda T, Tahara M, Uchida N, Yamaguchi T (1986) Somatic embryogenesis from coffee callus and protoplast. In: Somers DA, Gengenbach BG, Biesboer DD, Hackett WP, Green CE (eds), Abstr. $6^{\text {th }}$ Int. Cong. Plant Tissue Cell Culture, Univ. Minnesota, Minneapolis. pp.137.

Yasuda T, Tahara M, Hatanaka T, Nishibata T, Yamaguchi T (1995) Clonal propagation through somatic embryogenesis of Coffea species. In: XVI Colloq. Sci. Int. Coffee. Kyoto, pp.392-402.

Zamarripa A, Ducos JP, Tessereau H, Bollon H, Eskes A, Pétiard V (1991) Développement d' un procédé de multiplication en masse du caféier par embryogenèse somatique en milieu liquide. In: XIV Colloq. Sci. Int. Coffee. San Francisco, pp.392-402.

Zamarripa A (1993) Étude et development de l'embryogenèse en millieu liquid du caféier (Coffea canephora P., Coffea arabica L. et l'hybrid Arabusta). Rennes, France, École National Sepérieure Agronomique. Thèse de doctorat. 